\title{
Dekreacja. Wypowiadanie Boga: Safona, Marguerite Porete i Simone Weil
}

\author{
Anne Carson
}




\section{Prezentacje}

Dekreacja.

Wypowiadanie Boga: Safona,

Marguerite Porete i Simone Weil

Anne Carson
(C) 2011 by Anne Carson. Opublikowano za zgodą agencji The Marsh Agency Ltd. działającej w imieniu Autorki.

TEKSTY DRUGIE 2017, NR 5, S. 219-238

DOI: 10.18318/td.2017.5.15

$\mathbf{T}$ en esej traktuje o trzech kobietach i będzie podzielony na trzy części. Część pierwsza poświęcona jest Safonie, greckiej poetce żyjącej w VII wieku p.n.e. na wyspie Lesbos, autorce wspaniałej poezji o miłości oraz kulcie bogini Afrodyty, na którym koncentrowało się jej życie. Część druga mówi o postaci Marguerite Porete, która jako autorka książki o bożej miłości - dzieła uznanego przez papieską inkwizycję za heretyckie - została spalona na paryskim placu w 1310 roku'. Część trzecia opowiada o XX-wiecznej francuskiej filozofce Simone Weil, którą Albert Camus nazwał „jedynym wielkim duchem naszych czasów”.

\section{Część pierwsza}

A gdybym tak rozpoczęła esej poświęcony sprawom duchowym od przytoczenia wiersza, który, na pierwszy

1 Dokładnie na Place de Grève (czwarta dzielnica Paryża), gdzie odbywały się publiczne egzekucje; $w 1802$ roku zmieniono nazwę na Place de l'Hôtel de Ville. [przyp. tłum.]
Anne Carson - prof., poetka, eseistka, tłumaczka. Laureatka licznych nagród m.in.: Lannan Literary Award (1996), Griffin Poetry Prize (2001, 2014), Los Angeles Times Book Prize (2001), T.S. Eliot Prize (2001), Pen Award for Poetry (2011). Ostatnio opublikowała: The Albertine Workout (2014), Nay Rather (2014), Float (2016). 
rzut oka, nie ma nic wspólnego z duchowością? W trzydziestym pierwszym fragmencie Safona pisze:

Wydaje mi się dorównywać bogom

Mężczyzna, który naprzeciwko ciebie

Siedzi i chłonie z bliska, urzeczony,

Słodkie twe słowa,

Słuchając śmiechu, co budzi pragnienie.

I moje serce w piersi on dziś spłoszył,

Bo ledwie spojrzę na ciebie, nie umiem

Dobyć już głosu,

Język się łamie, delikatny ogień

Pod skórą ciało me nagle przebiega,

W oczach mrok, widzieć przestaję zupełnie,

W uszach mych szumi,

Pot mnie oblewa, dreszcz przejmuje całą,

Robię się bardziej zielona od trawy

I sama sobie bliską śmierci wtedy

Już się wydaję.

Lecz wszystko można znieść, bo i biednego... ${ }^{2}$

[przełożył Jerzy Danielewicz]

Wiersz ten zachował dla nas Longinus, starożytny krytyk literacki, który przytacza cztery pełne strofy, a następnie pierwszy wers czegoś, co jest prawdopodobnie początkiem piątej strofy, by nagle - nie wiadomo, z jakiego powodu - urwać przytoczenie. Pierwsze cztery strofy wydają się jednak tworzyć pewną muzyczną i myślową całość; rozpatrzmy to, co należy do sfery myśli. Myśl pojawia się w świetle, w osobliwie izolowanym świetle introspekcji. Safona wystawia ten scenariusz w teatrzyku swojego umysłu. Scenariusz zdaje się mieć charakter erotyczny, lecz postaci pozostają anonimowe, ich

2 Liryka starożytnej Grecji, oprac. J. Danielewicz, Ossolineum, De Agostini Polska, Warszawa-Poznań 1996, s. 186-187. Zob. także przekład Janiny Brzostowskiej (Liryka starożytnej Grecji, oprac. J. Danielewicz, wyd. 2 zmienione, Ossolineum, Wrocław 1984, s. 39-40). 
relacje - niejasne. Nie wiemy, co jest przyczyną śmiechu dziewczyny, jaką rolę odgrywa tam mężczyzna, ani nawet, jakie znaczenie tworzy reakcja Safony na te postaci. Ma się wrażenie, że bardziej interesuje ją powoływana przez nie figura geometryczna niż one same jako jednostki. Ta figura składa się z trzech linii i trzech punktów widzenia. Pierwsza linia łączy głos i śmiech dziewczyny ze słuchającym uważnie mężczyzną. Druga - dziewczynę z Safoną. Między okiem Safony i słuchającym mężczyzną przebiega linia trzecia. Tą figurą jest trójkąt. Dlaczego Safona ją inscenizuje? Rozsądek podpowiada, że jest to wiersz o zazdrości. „Objawy zazdrości występują szczególnie u kochanków", zauważa Longinus. Zastanówmy się więc, czym jest zazdrość kochanków.

Słowo zazdrość pochodzi od starogreckiego zelos i oznacza „żarliwość" lub „pościg”. Kochanek spogląda z zazdrością na pewne miejsce, które zlokalizowane jest w centrum uczuć ukochanego, ale czyni to tylko po to, żeby stwierdzić, że jest już ono zajęte przez kogoś innego. Jeśliby zazdrość była tańcem, byłby ten taniec relacją osiedlenia i wysiedlenia. Jej emocjonalny stan jest niestabilny. Zazdrość to taniec, w którym wszyscy się poruszają.

Safona przygotowuje scenę zazdrości, wcale jej jednak nie tańczy. W rzeczywistości zupełnie zapomina, już po pierwszej strofie, o swoich partnerach i zwraca światło reflektora na samą siebie. To, co widzimy w snopie światła, okazuje się inscenizacją ducha. Safona opisuje sprowadzaną do stanu dysfunkcji percepcję (wzrok, słuch, dotyk); obiekty należące do zewnętrznych zmysłów same siebie opróżniają; i tam, w jasnym świetle, na scenie w centrum percepcji pojawia się - jej własne Bycie: „Robię się...”, pisze Safona w piętnastym wersie („bardziej zielona od trawy”).

Nie jest to chwila objawienia się egzystencji: jest to duchowe zdarzenie. Safona popada w ekstazę. „Bardziej zielona od trawy”, mówi, uznając własne Bycie za cechę dającą się obserwować jedynie spoza własnego ciała. Ten stan określa się ekstaza, dosłownie znaczy „wyjście poza siebie”, przez Greków uznawany jest za typowy dla osób obłąkanych, geniuszy i kochanków, Arystoteles przypisywał go także poetom.

Ekstaza przemienia Safonę, przemienia wiersz. Jej świadomość, jak czytamy, ledwie żyje. Z kolei wiersz pojawia się i ulega rozpadowi, zostaje urwany. Jest jednak prawdopodobne, że zarówno świadomość, jak i utwór powstają potem na nowo. Mówię , jest prawdopodobne”, gdyż ostatni wers ma zagadkową historię i niektórzy uczeni podają jego istnienie w wątpliwość, mimo że pojawia się u Longinusa, a papirus tylko to potwierdza. Spróbujmy spojrzeć, jak wers ten łączy się z tym, co go poprzedza. 
„Lecz wszystko można znieść, bo i biednego...", mówi ostatni wers. Jest to nowa myśl. Treść tej myśli dotyczy absolutnego zniesienia. Jej warunkiem jest ubóstwo. Nie chcę sprawiać wrażenia, że wiem, o czym wers siedemnasty mówi i w jakim kierunku powinien podążać, nic z tych rzeczy. Tak naprawdę pozostawia mnie on zdumioną. Safona inscenizuje zazdrość, nie o niej jednak traktuje wiersz, zazdrość jest tutaj tylko figurą. Safona inscenizuje zdarzenie ekstatyczne, ale o tym też nie mówi się w wierszu, ekstaza to tylko środek prowadzący do celu. Tak się jednak nieszczęśliwie składa, że nie docieramy do celu, wiersz się urywa. Ale widzimy, że Safona zaczyna zwracać się w jego stronę, tj. w kierunku nieosiągalnego końca. Jesteśmy świadkami opróżniania się jej zmysłów, jesteśmy świadkami wyrzucenia jej Bycia poza centrum, gdzie stoi i patrzy na siebie, jak gdyby była martwa i przypominała trawę. W tym miejscu pojawia się pytanie: czy uznając ten wiersz za wiersz miłosny, jesteśmy zmuszeni odczytywać go jako utwór wyłącznie lub też konwencjonalnie erotyczny? W końcu Safona przedstawiana jest przez niektórych historyków jako poetka miłości i wyznawczyni Afrodyty z Lesbos, ale także jako kapłanka oddana kultowi bogini czy nawet wychowawczyni wyznająca jej doktryny. Być może wiersz Safony mógłby nas czegoś nauczyć o metafizyce czy nawet teologii miłości. Nie wnosi on typowej dla miłosnych piosenek skargi, „dlaczego mnie nie kochasz?”, w zamian stawia znacznie poważniejsze duchowe pytanie, „co świadomość znosi w miłości?” Zniesienie zjawia się w wierszu na samym końcu, kiedy Safona używa słowa tolmaton, co też polski tłumacz oddaje jako „można znieśćn"s.

Jest to przymiotnik odczasownikowy i wyraża stan, w którym coś jest potencjalne lub prawdopodobne. Safona mówi, że jest to absolutnie potencjalne - pan tolmaton: wszystko można znieść. Co więcej zgadza się na zniesienie - albo wydaje się kierować ku zgodzie w momencie, gdy wiersz się urywa. Dlaczego tak się dzieje? Nie znamy dalszego ciagu. Safona powraca do ekstatycznego stanu. Tam zadaje pytanie: „co świadomość znosi w miłości?” - i odpowiada: „świadomość znosząc się w miłości, pozostawia siebie za sobą, otwiera się na brak".

3 Należy wziąć pod uwagę wieloznaczność słowa „znieść (się)”: po pierwsze - zdjąć i przenieść, usunąć i przemieścić, nosić i gromadzić; po drugie - zboczyć z kursu, być porwanym w innym kierunku, sprawić, że coś zostanie zdruzgotane, rozbite, zerwane; po trzecie - unicestwić, zniszczyć, zrównać z ziemią; po czwarte - spowodować zanik czegoś, unieważnić, skasować (np. za sprawą innego tekstu, dokumentu, zarządzenia) itd. [przyp. tłum.] 


\section{Część druga}

Marguerite Porete została spalona na stosie w 1310 roku za napisanie książki o absolutnym zniesieniu się w miłości. Zwierciadło dusz prostych ${ }^{4}$ jest traktatem teologicznym, ale także rodzajem poradnika dla ludzi poszukujących Boga. Główne twierdzenie, którego Maguerite Porete dowodzi w swym dziele, dotyczy ludzkiej duszy zdolnej przejść przez siedem odmiennych faz miłości, poczynając od „palącego pragnienia” (MP 118), a kończąc na ekstazie, za sprawą której dusza przenosi się poza własne Bycie i pozostawia siebie za sobą. To wyjście poza swoje centrum nie jest bierne. Marguerite, tak jak Safona, odnajduje w świecie rzeczywistym pewne absolutne żądanie, które do siebie dopuszcza. Dzięki temu może się uznać za rozdzieloną na dwie i doświadczyć tego rozdzielenia jako czegoś w rodzaju „anihilacji”. Rozumowanie Marguerite jest dość ryzykowne: istota ludzkiej świadomości, jak twierdzi, zawiera się w wolnej woli, a wolna wola została jej dana w taki sposób, że potrafi ją zwrócić. Dlatego też może sprawić, że wola oddzieli się od niej samej i zostanie oddana Bogu, nic więcej sobie nie pozostawiając. Tak Porete opisuje to zdarzenie:

zachwycający rozrost ruchu boskiego światła jest wlewany do duszy i ukazuje się woli [jako słuszność... ustanawiana przez ruch duszy] w miejscu, w którym teraz dusza się znajduje i gdzie nie powinna więcej się pojawić, uniemożliwiając sobie powrót tam, skąd przyszła, gdzie jej nie ma i gdzie powinna pozostać. Wola dostrzega teraz... że nie uzyska żadnych korzyści, jeżeli nie wyjdzie poza własną wolę. I tak oto dusza oddziela się od woli i takoż wola oddziela się od duszy i oddaje się, wręcza sama siebie Bogu i wraca do Niego, skąd po raz pierwszy ją podjęto, nie zatrzymując sobie nic dla siebie... (MP 118)

Warto teraz zauważyć, w kontekście znaczeń przypisywanych ekstazie przez Safonę i związanych z ekstazą konsekwencji, że Marguerite Porete

4 M. Porete Le Mirouer des simples âmes anienties et qui seulement demeurent en vouloir et desir d'amour, red. R. Guarnieri, „Archivio Italiano per la storia de la Pietà" 1965 nr 4, s. 513-635. Tekst napisany w starofrancuskim; istnieją dwa powstałe niedawno tłumaczenia na język angielski, korzystam z nich, wprowadzając nieznaczne zmiany: M. Porete The Mirror ofSimple Souls, trans. E.L. Babinsky, Paulist Press, New York 1993; M. Porete The Mirror of Simple Souls, przeł. E. Colledge, J.C. Marler i J. Grant, Notre Dame University Press, Notre Dame 1999. [Wszystkie odniesienia do traktatu zostaną zaznaczone w tekście skrótem MP z numerem rozdziału. Tekst podany w przekładzie własnym - przyp. tłum.] 
dwukrotnie odnosi się do siebie w chwili, gdy boska obfitość wypełnia ją tak, że: „Ja jest w otchłani absolutnego braku” (MP 38). Opisuje również swoje zubożenie jako stan psychicznej i metafizycznej negacji: „Właśnie teraz dusza jest niczym, widzi bowiem swoją nicość jako boską obfitość, co sprawia że jest niczym i umiejscawia ją w nicości" (MP 118).

W Zwierciadle autorka określa się nieważną, bezwartościową, niepotrzebną, ogołoconą i nagą. W tym samym jednak czasie rozpoznaje swój brak jako wspaniały i niewyrażalny rodzaj sytości; i z tej absolutnej pustki, która jest zarazem absolutną pełnią, zwraca się do Boga w słowach pełnych erotyzmu: „przepełniający i płodny kochanku”,,,małżonku mojej młodości” $(\mathrm{MP} 38,118)$. Jeszcze bardziej interesujące od wspomnianej analogii jest to, że Marguerite dwukrotnie przedstawia zazdrość jako figurę relacji z Bogiem. Co więcej, określa go "najbardziej zazdrosnym”, opowiadając o związku jej duszy z Bogiem w ten sposób:

Prawdziwa jest jego zazdrość! Potwierdzają to jego dzieła, za sprawą których doszczętnie rozebrał mnie z siebie i doprowadził do boskiej rozkoszy beze mnie! Ten związek pozwolił mi spotkać się i połączyć przez najwyższą siłę stworzenia ze wspaniałością boskiego bycia, dzięki któremu posiadam istniejące życie. (MP 71)

Oto i niezwykły trójkąt erotyczny tworzony przez Boga, Marguerite i Marguerite. Jego ruch przyczynia się jednak do tej samej ekstazy, jaką znamy z wiersza Safony i przedstawionego tam zdarzenia, w którym brały udział trzy postaci. Marguerite odczuwa, że jej świadomość zostaje oddzielona od niej samej i rzucona w stan zubożenia, na który wyraziła zgodę. Zgoda przybiera formę osobliwie intensywnej fantazji na temat erotycznego trójkąta:

tak też rozmyślam, czy jeśliby Bóg zapytał mnie, co uczyniłabym, gdybym wiedziała, że jestem przeznaczona do miłości przekraczającej jego samego...? Ale nie wiem, co mogłabym odpowiedzieć, zawodzą mnie zmysły. Następnie Bóg zapytał, co zrobiłabym, gdyby kochał mnie miłością przekraczającą mnie samą? I w tym punkcie zawodzą zmysły, nie potrafię odpowiedzieć... Później zapytał, co uczyniłabym, gdyby zechciał kochać mnie bardziej niż on sam? Tutaj padłam zemdlona, co by w żadnej z tych trzech spraw nie zabrać głosu, ani nie odmówić, ani nie zaprzeczyć. (MP 131) 
Zwróćmy uwagę, w jaki sposób Marguerite obraca fantazję w różne strony, zmieniając biorące w niej udział postaci i ponownie wyobrażając sobie powodowane fantazją cierpienie. Zazdrość to taniec, w którym wszyscy się poruszają. To taniec, którego istota poddana jest dialektyce. W sercu zazdrosnej kochanki musi istnieć równowaga - oparta na sprzeczności - między jedną i drugą rzeczywistością: z jednej strony jest ta stanowiąca jej własność, usytuowana w centrum wszechświata i podlegająca woli, okazująca miłość ukochanemu; z drugiej sytuująca się poza centrum i niepodporządkowana woli, przyglądająca się ukochanemu, który darzy miłością kogoś zupełnie innego. Zderzenie tych dwóch rzeczywistości prowadzi zakochanego do czegoś w rodzaju rozbicia - jak widzieliśmy w wierszu Safony - w rezultacie Bycie poddane zostaje analizie i usuwa się z centrum. Jest to prawdopodobnie wyjątkowo trudny sprawdzian dialektycznej wytrzymałości, dzięki któremu jesteśmy w stanie zgodzić się na to rozbicie, a nie tylko je rozpoznać. Safona zdaje się przekraczać próg stanu, w którym ta zgoda się pojawia. Wiersz zostaje jednak urwany. Zanim Marguerite stawi temu czoła, trzykrotnie padnie zemdlona. Ale wówczas, z psychologiczną przejrzystością, równie olśniewającą jak u Safony, podda się skutkom własnego bólu. Oto i analiza tego, co dostrzega Marguerite, spoglądając do swego wnętrza:

I tak długo jak trwałam w dostatku i miłości „z” nim, nie potrafiłam się opanować i być spokojna: zniewolona nie mogłam się poruszyć... Kochałam samą siebie razem „z" nim tak bardzo, że nie potrafiłam odpowiadać uczciwie... Lecz nagle zażądał mojej odpowiedzi; gdybym nie odpowiedziała, straciłabym nas oboje, siebie i jego... Odpowiedziałam, że musi chcieć sprawdzić mnie w każdym szczególe. (MP 131)

Marguerite sięga dna, a kiedy zdaje sobie sprawę, że lojalność wobec Boga przesłania w rzeczywistości jej miłość do niego, ponieważ - tak jak większość ludzkich potrzeb erotycznych - miłość ta jest w dużej mierze troską o samego siebie: i w ten sposób nie Bóg wtrąca do niewoli Marguerite, czyni to sama z sobą Marguerite. Porete posługuje się w swoim wywodzie figurą zazdrości w dwojaki sposób. W zazdrości dostrzega wyjaśnienie własnych odczuć dotyczących wewnętrznego rozdzielenia; przedstawia też zazdrość jako sprawdzian możliwości decentralizacji samej siebie, jako sposób na oczyszczenie serca i woli, wreszcie powód, dla którego może zejść z drogi prowadzącej do Boga. Odpowiadając uczciwie, jak sama mówi, nie może być dalej jednością z sercem czy też wolą, nie może kochać swoją miłością, kochać, kochając, ani 
też kochać, będąc kochaną. Na tyle, na ile potrafi wszystko to „anihilować”, jest też zdolna sprowadzić trzy punkty widzenia w tańcu zazdrości w jedną nagość, ograniczając tym samym własne Bycie z trzech do dwóch i do jednego:

Teraz ta dusza... pozbyła się trzech i uczyniła z dwóch jedną. Ale na czym opiera się ta jedna? Jest jedną, gdy dusza dana jest w prostocie Boga, w pełni wiedzy, bez żadnego uczucia, poza myślą... W wysokości, której nie sposób sięgnąć, w głębi, której nikt nigdy nie zgłębi, w nagości, w której żaden człowiek być nie może. (MP 138)

\section{Część trzecia}

Simone Weil także pragnęła znieść siebie i dotrzeć do Boga. W jednym ze swoich notatników zapisała: „Świadomość jest zaledwie cieniem - cieniem ukazującym się dzięki grzechowi i omyłce - który ogranicza Boskie światło i który biorę za Bycie". Sformułowała program zniesienia siebie samej, nazwała go "dekreacją"5. Nie zdefiniowała jednak tego neologizmu, nie dała też żadnej spójnej jego wykładni. „Zniweczyć tę istotę wewnątrz nas”, oto jeden z celów dekreacji ${ }^{6}$. Kiedy Weil mówi o metodach, jakimi posługuje się dekreacja, korzysta z języka, który może brzmieć znajomo. Tak jak Marguerite Porete, wyraża potrzebę oddania Bogu tego, co zostało jej ofiarowane, czyli świadomości: „Na tym świecie nie posiadamy nic, oprócz zdolności mówienia «ja». To właśnie musimy zwrócić Bogu" (SW 71).

Simone Weil opisuje zwrócenie świadomości Bogu, podobnie jak Marguerite Porete, jako pewien rodzaj próby:

Bóg dał mi Bycie po to, abym je Mu zwróciła. To niby jedna z tych pułapek, za sprawą których postaci w bajkach są poddawane próbie. Jeśli przyjmę ów dar, będzie to złe i fatalne w skutkach; korzyści, jakie przynosi mi ten

5 Polski czytelnik odnajdzie rozdziały "poświęcone” dekreacji, albo też de-kreacji (jak proponuje Czesław Miłosz) czy nawet od-twarzaniu (jak podaje Aleksandra Olędzka-Frybesowa) w: S. Weil Wybór pism, przeł. i oprac. C. Miłosz, Znak, Kraków 1991, s. 119-124; S. Weil Świadomość nadprzyrodzona. Wybór myśli, przeł. A. Olędzka-Frybesowa, wyb. i oprac. J. Nowak, Instytut Wydawniczy PAX, Warszawa 1986, s. 99-107, 125-127 oraz S. Weil Myśli, przeł. A. Olędzka-Frybesowa, Instytut Wydawniczy PAX, Warszawa 1985, s. 164-169. [przyp. tłum.]

6 S. Weil Gravity and Grace, przeł. A. Wills, University of Nebraska Press, Lincoln-Nebraska 1997, s. 81. Przekład nieco zmieniony. [Wszystkie odniesienia do książki zostaną zaznaczone w tekście skrótem SW z numerem rozdziału. Tekst podany w przekładzie własnym - przyp. tłum.] 
dar, staną się widoczne za sprawą mojej odmowy. Bóg pozwolił mi egzystować poza nim samym. Podług mnie jest to równoznaczne z odrzuceniem tego pozwolenia. (SW 87)

I znów przychodzi na myśl Marguerite Porete, gdy Weil traktuje siebie jako przeszkodę na drodze prowadzącej do swego wnętrza. Proces dekreacji wiąże się ze zniesieniem się z centrum, w którym nie może pozostać, gdyż w ten sposób blokuje dostęp do Boga. Wspomina o potrzebie „wycofania się ze swej duszy”, by za chwilę dodać: „Bóg zdolny jest w nas kochać jedynie to przyzwolenie do wycofania się, które otwiera mu przejście" (SW 88).

Zastanówmy się przez chwilę nad twierdzeniem o przyzwoleniu i wycofaniu. Simone Weil rozpoczyna negocjacje wymagające wyjątkowej odwagi i ogromnego wysiłku, to właśnie przybliża ją do Marguerite Porete i Safony. Simone Weil pragnie odkryć w trójkątnej figurze zazdrości linie siły wiążące duszę i Boga. Nie fantazjuje jednak o relacjach ze zwykłymi, ludzkimi kochankami. Konstruuje trójkąt zazdrości, włączając do niego Boga, własną osobę i wszelkie dzieło stworzenia:

Wszystkie te rzeczy, które widzę, słyszę i jem, których dotykam, którymi oddycham; wszystkie stworzenia, które spotykam - pozbawiam w całości tego, co łączy je z Bogiem, i Boga pozbawiam relacji z tym wszystkim tak dalece, że coś we mnie mówi „ja”. Potrafię uczynić coś dla tych wszystkich rzeczy, jak i dla samego Boga - mianowicie wycofać się i poszanować ich tête-à-tête...

Muszę się wycofać, żeby Bóg połączył się z tymi stworzeniami, których szanse spoczywają na mej drodze i które on kocha. Przebywanie tam, tak jak to widzę, jest nietaktowne. Jakbym znajdowała się między dwójką przyjaciół czy zakochanych. Nie jestem dziewczyną czekającą na narzeczonego, lecz tą trzecią, która, nieproszona, zawadza i której powinni się pozbyć, żeby mogli naprawdę być razem.

Gdybym tylko wiedziała, jak zniknąć, powstałby doskonały miłosny związek między Bogiem i ziemią, po której chodzę, i morzem, które słyszę... (SW 88)

Gdyby tylko Simone Weil stała się tym, co Marguerite Porete nazwała „unicestwioną duszą", gdyby osiągnęła transparentność ekstatycznego stanu, w który popada Safona „bardziej zielona od trawy / I sama sobie bliską śmierci", wówczas mogłaby uznać, że uwolniła świat od niedyskrecji. Zazdrość jest 
tańcem, w którym każdy się porusza, bo też o jedną osobę jest wśród tańczących za dużo - jak w grze w gorące krzesła. W tekście Marguerite Porete ta dodatkowa osoba wyróżniona jest poprzez sprytne użycie cudzysłowów: pamiętamy jej płaczliwą konstatację: „Kochałam samą siebie razem «z» nim tak bardzo, że nie potrafiłam odpowiadać uczciwie" (MP 131).

Kiedy po raz pierwszy przeczytałam to zdanie, wydało mi się dziwne, że Marguerite ujęła w cudzysłów „z", a nie, jak można się było spodziewać, zaimek. Ale ona wiedziała, co robi: to nie ludzie stanowią tutaj problem. Problemem jest bliskość. Marguerite Porete próbuje posłużyć się najprostszym językiem i niewyszukanymi znakami do wyrażenia złożonej duchowej rzeczywistości. Co oznacza, że nie mogę pójść z miłością do Boga bez samej siebie. Dlatego też w najgłębszym sensie nie jestem w stanie być sama z Bogiem. Mogę być tylko sama „z" Bogiem.

Dostrzeżenie tego faktu uwalnia percepcję, przymusza patrzącego do odnalezienia się w miejscu, gdzie zniknie sam dla siebie, żeby móc widzieć. Jak to rozkosznie opisuje Simone Weil: „Mogę zobaczyć krajobraz takim, jakim jest naprawdę, jedynie w chwili, gdy mnie w nim nie ma. Ale gdziekolwiek bym nie była, bicie mojego serca zakłócać będzie ciszę nieba" (SW 89).

Widzimy, że Marguerite Porete odnalazła sposób przełożenia bicia swego serca na cudzysłów ujmujący słowo „z". A i Safona wynalazła zapis uderzeń serca, kiedy wyobrażana jest jego nieobecność - tę funkcję pełni w jej wierszu niechybnie „Mężczyzna, który naprzeciwko ciebie / siedzi i chłonie z bliska, urzeczony”. Mężczyzna, jak mówi nam Safona, „wydaje [...] się dorównywać bogom”; ale czy nie możemy wziąć go za przedstawienie „krajobrazu takim, jakim jest naprawdę, jedynie w chwili, gdy mnie w nim nie ma"? Radość w tym krajobrazie jest tak obejmująca, że nie daje się doświadczyć. Safona nie kontynuuje jego opisu, Marguerite Porete zdaje zaś niezwykłą relację duszy, która przebywa w tym stanie:

Ta dusza... pływa w morzu radości - to znaczy w morzu radości, które wypływają i napływają od Boga, i nie odczuwa radości tego, co dla niej samej jest radością, pływa w niej i jest przez nią niesiona, choć nie może jej w żaden sposób zaznać, ponieważ zamieszkuje radość i radość ją zamieszkuje... (MP 28)

Blisko stąd do stworzonego przez Simone Weil projektu dekreacji, który nierozpoznany jako rodzaj bezradosnej radości - nie stanowi okazji do kąpieli, lecz do wykluczenia i negacji: „Czysta radość wyklucza nawet największą 
radość, w duszy wypełnionej przez obiekt nie znajdzie się najmniejszy kąt, w którym «ja» może być wypowiedziane" (SW 77).

\section{Część czwarta}

Jako że wkraczamy właśnie w część czwartą trzyczęściowego eseju, powinniśmy być gotowi na odrobinę niekonsekwencji. Nie sądzę, żebym była tej niekonsekwencji przyczyną. Jej powodem są raczej te trzy kobiety, którym się przyglądaliśmy, ale również fakt, że wszystkie są pisarkami. Kiedy Safona mówi, że jest „całą”, lecz „bliską śmierci”, kiedy Marguerite Porete przyznaje, że pragnie stać się „unicestwioną duszą", kiedy Simone Weil stwierdza, że „uczestniczymy w kreacji świata przez dekreację samych siebie”, to czy możemy oddać te niejasne idee w doskonale przejrzystym projekcie pisarskim dzielonym na nie wszystkie, projekcie wypowiadania świata prawdy o Bogu, miłości i rzeczywistości? Odpowiedź brzmi: nie możemy. Nie bez przyczyny Marguerite Porete zatytułowała swoją książkę Zwierciadło. Żeby być pisarzem, należy skonstruować wielkie, lśniące i rozległe centrum świadomości, gdzie pisaniu oddaje się głos; jeśli pojawi się tam jakiekolwiek twierdzenie zdolne unicestwić świadomość, nie zatrzymując jednak samego procesu pisania i oddawania mu głosu, musi ono uwzględniać piszącego w jakichś istotnych aktach będących formą podstępu lub sprzeczności.

Wszystko to powinno zwrócić naszą uwagę na sprzeczność i sposoby jej użycia. Simone Weil mówi o tym wyraźnie:

Sprzeczność sama w sobie uświadamia nam, że nie jesteśmy wszystkim.

Sprzeczność stanowi o istniejącym w nas złu, a poczucie naszego zła odpowiada poczuciu rzeczywistości. Nie wymyślamy sobie naszego zła. To prawda. (SW 148)

Zaakceptowanie zła tkwiącego w istocie ludzkiej stanowi dla Simone Weil początek dialektyki radości: „Jeśli odnajdujemy pełnię radości w myśli, jaką Bóg jest, musimy odnaleźć tę samą pełnię w wiedzy, której my sami nie posiadamy, z powodu tej samej myśli" (SW 84).

Nic i coś są dwiema stronami tej samej monety, przynajmniej w umyśle dialektyka. Marguerite Porete tak przedstawia tę kwestię: „Nic jest niczym. Coś jest tym, czym jest. Dlatego nie jestem, jeśli jestem czymś, z wyjątkiem tego, czym Bóg jest” (MP 70). Mówi również: „Panie, jesteś ogromną dobrocią, dzięki otwartej całkowicie na ciebie dobroci. 
A ja jestem ogromnym złem, dzięki otwartemu całkowicie na siebie złu" (MP 130).

Wizja stworzona przez Marguerite Porete nie jest tragiczna, lecz dialektyczna: wyobraża sobie jakąś formę odwróconej immersji czy też wspólnej absorpcji w taki sposób, w którym te dwa absolutne przeciwieństwa - Bóg oraz dusza - mogą być w końcu jednym. Posługuje się różnego rodzaju obrazami takiego zjednoczenia, np. obrazem żelaza, które, kiedy ułożone zostaje na palenisku, przemienia się w ogień; albo rzeki, która traci swe imię, wpadając do morza (MP 25, 82). Te proste obrazy przenoszą nas poza dialektyczną relację Boga i duszy; przez dialektykę rozumiem tu drogę rozumowania i intelektualne zastosowanie świadomości. Jednakże dusza przywiedziona za sprawą miłości przed oblicze Boga, dusza przemieniona w ogień, rozpuszczona przez wodę - otóż dusza nie posiada nienaruszonego intelektu, jakim dysponuje zwykła istota ludzka i za sprawą którego konstruuje ona dialektyczne relacje. Innymi słowy, omija ona miejsce, gdzie może mówić to, o czym wie. Funkcją świadomości jest mówić.

Dla pisarza taka sytuacja jest wyjątkowo problematyczna. To już nie tyle sprzeczność, ile paradoks. Marguerite Porete porusza ten problem we wczesnych partiach Zwierciadła, z charakterystyczną pewnością siebie:

Ktokolwiek mówi o Bogu... musi nie wątpić, ale wiedzieć bez wątpliwości... w innym przypadku nigdy nie pozna istoty prawdziwej Bożej miłości, która całkowicie oślepia niezdającą sobie z tego sprawy duszę. To jest prawdziwie czysta istota Bożej miłości, która pozbawiona jest materii i dana stworzeniom przez Stwórcę, odbierająca catkowicie zdolność mówienia. (MP 18, podkreślenie dodane) ${ }^{7}$

W tym miejscu Marguerite porusza kwestię pisarstwa. Każdy, kto mówi o Bogu, nie doświadczył jego miłości, twierdzi Marguerite, ponieważ miłość ta „odbiera całkowicie zdolność mówienia”.W dalszej części traktatu wzmacnia argumentację: duszę, która raz doświadczyła Bożej miłości, zrozumie ponownie tylko sam Bóg (MP 19, 20). Możemy teraz postawić pytanie: co też takiego Marguerite Porete czyni w pozostałych rozdziałach swojej książki,

7 Tekst rozdziału osiemnastego budzi kontrowersje: najstarszy ocalały manuskrypt książki Marguerite Porete w języku starofrancuskim (sporządzony około 1450 roku) nie zawiera fragmentu kursywą, natomiast starszy przekład na łacinę (około 1350 roku) już tak. Zob. P. Verdeyen La première traduction latine du Miroir de Marquerite Porete, "Ons Geestelijk Erf" 1984 No 50, s. 388-389. 
która liczy ich łącznie sto trzydzieści dziewięć, kiedy krok po kroku opisuje duszę dążącą do unicestwienia w Bogu? Możemy również zastanowić się, o czym tak naprawdę tam się mówi. Jest jednak mało prawdopodobne, żebyśmy otrzymali odpowiedź. Możliwe też, że nie rozstrzygnie tego, jak myślę, żaden rozsądny pisarz, który w swoim pisarstwie oddaje się Bogu i duchowym spekulacjom. Ale nas zastanawia jedynie to, w jakim stopniu pisarz czuje się zobowiązany do rozstrzygania o tych kwestiach. Przyjrzyjmy się dokładnie, jak takie zobowiązanie pisarza się objawia. Powiedzieliśmy już, że funkcją świadomości jest mówić. Jeśli rozpatrzymy, w jaki sposób każda z tych trzech pisarek mówi o swoim mówieniu, dojdziemy wreszcie do wniosku, że wszystkie one zobligowane zostały do stworzenia czegoś na kształt marzenia o oddaleniu, gdzie z centrum tekstu zostaje wymazana świadomość, zaś opowiadający znosi się w opowieści.

Zajmijmy się na początek Simone Weil, która była niezwykle rzeczową osobą i zaaranżowała swoje zniknięcie na kilku poziomach. Wierzyła między innymi w przyspieszenie nadejścia swojej śmierci - spowodowanej gruźlicą w 1943 roku - przez narzucenie sobie reżymu dobrowolnej głodówki, której podjęła się na znak solidarności z głodującymi we Francji. Kiedy w 1942 roku jej rodzice zdecydowali porzucić Francję i uciec do Ameryki, towarzyszyła im krótko i niechętnie, powierzając pewnemu Gustawowi Thibonowi (rolnikowi, właścicielowi winnicy, w której pracowała) prawie tuzin notatników zawierających osobiste refleksje (stanowią one dzisiaj znaczną część jej opublikowanych prac). W jednym z listów pisała, że może on uczynić wszystko z myślami, które zawarte są w notatnikach:

Tak więc teraz należą do ciebie i wierzę, że kiedy już przemienią się w tobie, nadejdzie też dzień, w którym pojawią się w jednej z twych prac... Byłabym bardzo szczęśliwa na ich miejscu, odnajdując schronienie pod twoim piórem, który przemieni ich kształt tak, by mogły odzwierciedlać twoją osobę...

W trakcie pisania ręka, która trzyma pióro, i ciało, i dusza, która jest wraz z nim, są to rzeczy niepomiernie małe w przestrzeni ustanowionej przez nicość. (SW 11)

Gustave Thibon nie spotkał już Simone Weil, nie zastosował się również do wyrażonej przez nią woli, która, choć niewypowiedziana do końca, dotyczyła przekształcenia jej myśli w jego. W zamian zapoznał się z notatnikami, wydobył napisane z werwą fragmenty, pogrupował je w kolejne działy 
i nadał tytuły „Świadomość”, „Pustka”, „Niemożliwość”, „Piękno”, ,Algebra”, „Szczęście”, „Znaczenie wszechświata”, by następnie opublikować je w formie książkowej; na jej pierwszej stronie widniało imię i nazwisko: Simone Weil'. Wymagało to wielkiego nakładu pracy, Thibon miał przywrócić ją własnemu centrum i stanowi, którego sama unikała; takie przywrócenie niezwykle trudno ocenić z zewnątrz, z perspektywy, jaką dysponujemy jako czytelnicy. Jakkolwiek uwielbiam ten ostateczny, a zarazem jakże łagodny fragment rady, jakiej udziela Thibonowi w zakończeniu listu z 1942 roku:

Lubię wyobrażać sobie, że po nieznacznym wstrząsie, jaki spowoduje nasze rozstanie, nie będziesz odczuwał żadnego smutku związanego z tym, co mogłoby mnie czekać, a jeśli się zdarzy pewnego razu, że o mnie pomyślisz, to wspomnij mnie jak czytaną w dzieciństwie książkę... (SW 12)

Kiedy myślę o książkach czytanych w dzieciństwie, jawią mi się w gwałtownym perspektywicznym skrócie, okolone groźną ciemnością, zarazem jednak promienieją jakąś nadnaturalną prawie intensywnością życia, której żadna lektura podejmowana w dorosłym życiu nie jest w stanie wywołać. Pamiętam książeczkę Żywoty świętych, którą podarowano mi gdy miałam około pięciu lat.W tej książce rozmaite kwiaty układały się w korony męczenników, którzy byli tak pysznie oddani słowem i pędzlem, że byłam zmuszona powstrzymywać się przed ich zjedzeniem. Zresztą to ciekawe, jaki smak mogły mieć dla mnie tamte strony. Choć może nagła chęć jedzenia nie była wcale związana ze smakiem. Może chodziło o znalezienie się na skrzyżowaniu sprzeczności, które to miejsce, jeśli już tam się znajdziemy, jest przyczyną bólu - i z tego też powodu dzieci, powodowane swym naturalnym rozsądkiem, nie chcą tam przebywać, mistycy zaś nie znają bardziej upragnionego miejsca. Tak jak i Simone Weil:

Największe nieszczęście człowieka, a bierze ono swój początek w niemowlęctwie i towarzyszy mu aż do śmierci, wiąże się z tym, że jedzenie i widzenie są dwoma różnymi czynnościami. Nieskończona błogość jest stanem, w którym patrzeć to jeść. (SW 153)

8 Fragmenty wprowadzenia przygotowanego przez Gustawa Thibona do pierwszego wyboru tekstów francuskiej filozofki, wydanego w Paryżu w 1948 roku pod tytułem La pesanteur et la grâce, odnajdzie polski czytelnik w przywołanej już książce S. Weil Świadomość nadprzyrodzona. Wybór myśli, s. 5-24. [przyp. tłum.] 
Simone Weil w ciągu całego swego życia miała problem z jedzeniem. Zresztą jak większość kobiet. Nic tak dotkliwie, nic też tak często nie przypomina nam o naszej fizyczności jak pożywienie i potrzeba jego spożywania. Z tego powodu Simone Weil stworzyła w swoim umyśle marzenie o oddaleniu: za jego sprawą można rozkoszować się pożywieniem jedynie dzięki przebiegającemu przestrzeń spojrzeniu, pożądanie nigdy nie gaśnie, a zakochany potrafi być w tym samym czasie bliski i daleki wobec swojego obiektu miłości.

Jedzenie i miłość są dla Simone Weil dwiema analogicznymi sprzecznościami. Nigdy ich nie zaznała, zawsze też czuła niepokój powodowany wyobraźniowym stosunkiem do nich. Mimo wszystko nieskończona błogość nie jest jedynym stanem, w którym patrzeć to jeść. Także zapisana strona jest w stanie zreifikować dla nas ten paradoks. Pisarz może powiedzieć zarówno to, co bliskie, jak i dalekie.

I tak, dla przykładu, w niezwykle oryginalnej terminologii, jaką posługiwała się Marguerite Porete, autorskie marzenie o oddaleniu staje się epitetem określającym Boga. Do opisu boskiego kochanka, który karmi jej duszę prawdą, Marguerite Porete tworzy słowo: le Loingprés w jej starofrancuskim, Longe Propinquus w przekładzie na łacinę, zaś w języku polskim „NajbliższyDaleki”. Marguerite nie wyjaśnia tego słowa, po prostu zaczyna go używać, jakby jego znaczenie było oczywiste, w pięćdziesiątym ósmym rozdziale swojej książki, w którym mówi o unicestwieniu. W momencie unicestwienia, jak czytamy, Bóg wypróbowuje na duszy niezwykłą siłę uwielbienia. Otwiera w duszy szczelinę, pozwalając by wypełnił ją boski spokój niby cudowne jadło. A czyni to jako le Loingprés, NajbliższyDaleki:

Jest tam szczelina, jak iskra, która szybko gaśnie, nie można w niej długo pozostać... Wylew z zachwycającej szczeliny uwalnia duszę, uwzniośla ją, pozbawia ciężaru, a jej spokój trwa tak długo, jak szczelina pozostaje otwarta... Co więcej spokój ten jest tak wyśmienity, że prawda określa go cudownym jadłem... (MP 58 )

Doskonały NajbliższyDaleki rozchyla tę szczelinę, w słodkim geście chwały, nie dłużej niż na mgnienie oka, skąd dusza, jak chce Bóg, bierze swoją chwałę, którą posiadać będzie bez końca. (MP 63)

Stworzony przez Marguerite Porete obraz Boga jako „doskonałego NajbliższegoDalekiego" jest niewątpliwie zmyśleniem. Ale jeszcze bardziej niewątpliwa jest zagadka, przed którą zmyślenie ją stawia: 
gdzie dusza spoczywa po wysiłku, jaki podjął zachwycający NajbliższyDaleki, co też nazwać możemy błyskiem w pewnego rodzaju szczelinie, tak szybko zamkniętej, że nikt nie uwierzy... czy też mogłaby ona zawieraćjakaś prawdę, która pozwalatby to wypowiedzieć. (MP 58, podkreślenie dodane)

Marguerite Porete umieszcza wewnątrz tego, co mówi, fałdę niedowierzania - rodzaj rysy na szkle - przypominając nam, że marzenie o oddaleniu nie jest niczym więcej jak snem. Na koniec książki powraca jeszcze raz do tej koncepcji: „Jego oddalenie jest bliższe” (MP 135). Nie mam pojęcia, co ten fragment mógłby oznaczać, niemniej przenika mnie na wskroś. Wypełnia zdumieniem. Przytoczone zdanie jest samo w sobie niewielką, acz skończoną ceremonią religijną, jak pieśń pochwalna czy modlitwa. Pieśni pochwalne i modlitwy są dzisiaj konwencjonalnym sposobem, w jaki ci, którzy ukochali Boga, zaświadczają o jego „NajbliższymOddaleniu”, w modlitwie zawiera się bowiem żądanie bezpośredniego kontaktu z Byciem, którego nieobecność wypełnia świat. Ale Marguerite Porete była dość niezwykłą kochanką Boga i nie trudziła się odmawianiem modlitw, uznając je za bezużyteczne. Inaczej Simone Weil, która, choć nigdy nie przyjęła chrztu, była mocno przywiązana do modlitwy, którą chrześcijanie znają jako „Ojcze Nasz”. Latem 1941 roku, w winnicy Gustawa Thibona, wykonując swoją pracę, nagle spostrzegła, że odmawia Modlitwę Pańską. Nigdy wcześniej nie odmawiała modlitw, jak zanotuje w jednym z zeszytów, efekt był doprawdy ekstatyczny: "Już pierwsze słowa odrywają moje myśli od ciała i przenoszą je do miejsca, które leży poza przestrzenią... napełniając każdy przejaw nieskończoności nieskończonością"9.

Modlitwa jest dla niej, jak się wydaje, doświadczeniem przestrzennej sprzeczności - albo dowodem na niemożliwą do udowodnienia prawdę boskiego ruchu. W innym fragmencie powraca do Modlitwy Pańskiej i jej nieosiaggalnej prawdy:

Ojcze Nasz, któryś jest w niebie. Jest w tym coś zabawnego. Jest On twoim Ojcem, spróbuj go jednak wypatrzeć tam w górze! Nie potrafimy wznieść się nad ziemię i w tej kwestii nie różnimy się od dżdżownicy. I jak on myśli zejść do nas bez zniżania się? Nie sposób wyobrazić sobie przymierza między Bogiem a człowiekiem, które byłoby tak niejasne jak inkarnacja. Inkarnacja eksploduje niejasnością. Jest to absolutnie właściwa droga,

9 S. Weil The Simone Weil Reader, ed. by G. Panichas, David McKay, New York 1977, s. 492. 
za sprawą której przedstawia się niemożliwe zstąpienie. Dlaczego to nie może być prawdą? (SW 148)

Dlaczego prawda nie może być niemożliwa? Dlaczego to, co niemożliwe, nie może być prawdą? Takie pytania są ogniwami, z których modlitwy są tworzone. Oto modlitwa Safony, ostatni przykład marzenia o oddaleniu, w którym pisarz mówi o Bogu:

Przyjdź do mnie z Krety, [do tego] przybytku

Przybądź świętego, gdzie gaj miłych tobie

Rośnie jabłoni i wonią kadzidła

Pachną ołtarze

Tu chłodna woda pośród jabłoniowych

Gałązek szemrze, róże ogród cały

Okryły cieniem, z migoczących liści

Sen jak czar spływa.

Tu łąka, koni pastwisko, rozkwita

Kwiatami wiosny, a wiatry słodyczą

Tchną miodu

Tutaj..... weź, Kiprydo,

I do pucharów złotych delikatnie

Nektar zmieszany z radościami uczty

Nalej jak wino. ${ }^{10}$

$$
\text { [przełożył Jerzy Danielewicz] }
$$

Fragment drugi został niestarannie wydrapany na kawałku garnca w III wieku p.n.e. Tekst jest błędny i niekompletny. Jakkolwiek potrafimy rozpoznać w nim rodzaj hymnu kletycznego, hymnu przyzywającego, inwokację do Boga o przyjście stamtąd, gdzie się znajduje, do miejsca, gdzie my jesteśmy. Taki rodzaj hymnu zazwyczaj określa obydwa miejsca, lokalizując jego inwokację pomiędzy, żeby możliwe było określenie różnicy - różnicy, która jest funkcją dekreacyjną hymnu - nie destrukcyjną, lecz dekreacyjną. Takie zdanie 
pojawia się wśród pozostawionych przez Simone Weil zapisków o dekreacji: "Bóg może być obecny w akcie kreacji tylko pod postacią nieobecności” (SW 162).

Dla autora hymnów kletycznych nieobecność Boga jest czymś trudnym, prawdopodobnie też niemożliwym do wypowiedzenia. Pisarz ten wzywa Boga, który przybywa wraz ze swoją nieobecnością - Boga, którego oddalenie jest bliższe. Jest to niemożliwy gest, możliwy jedynie w pisarstwie. Safona osiąga go za sprawą różnych zabiegów składniowych: np. przez usunięcie czasownika w pierwszym wersie wiersza. W przekładzie z wahaniem dodałam w nawiasie kwadratowym czasownik w trybie rozkazującym „przyjdź, uznając go za pierwszy wyraz utworu, który, jak wskazuje sens, powinien tam być, tekst grecki nie zawiera jednak tego czasownika, zaczyna się od przysłówka „tutaj”"1. Po prawdzie czasownik w trybie rozkazującym, na który cały wiersz, przez powolne i wezbrane onomatopeicznie zdania podrzędne, wydaje się czekać, pojawia się dopiero w ostatnich słowach naszego tekstu: „nalej”. Efekt tego napięcia jest osobliwy: jak gdyby całe dzieło kreacji zostało przedstawione w oczekiwaniu na działanie, które nieustannie jest już tutaj. Nie istnieje wyraźna granica między tym, co bliskie i dalekie; nie istnieje ten szczególny moment, w którym Bóg nadchodzi. Safona przedstawia układ warunków, od których z początku zależna jest nieobecność Afrodyty, by na koniec uwzględnić to, że bogini jest tu ciągle obecna. Odtwarza oddalenie Boga w czymś, co przypomina zawieszone rozstrzygnięcie - dzięki czemu widzimy Bycie Boga jako kroplę oślepiającą blaskiem, która w sposób niespodziewany i niemożliwy nasącza świat.

Podsumowując. Wszystkie trzy kobiety, których teksty analizowaliśmy, były na tyle odważne, żeby wkroczyć w przestrzeń absolutnego duchowego zniesienia. Każda z nich poddaje się doświadczeniu dekreacji albo tak o tym mówi. W ich mówieniu zachowała się jednak cząstka zdumienia. Dekreacja jest zgubą istoty wewnątrz nas - istoty zamkniętej w świadomości i definiowanej przez świadomość. Ale żeby znieść świadomość, należy się przez nią przedostać, do jej najgłębszej treści. Od tego musimy zacząć. I to jest właśnie pergamin, jak powie Marguerite Porete, na którym Bóg zapisuje swoje nauki.

11 Polscy tłumacze fragmentów Safony nie uwzględniają tego "braku”, uznając go prawdopodobnie za oczywisty, co więcej przekład dokonany przez Janinę Brzostowską, już sam w sobie wybujały, rozpoczyna się od słów: „z niebios... / przybądź więc tutaj z Krety” (Liryka starożytnej Grecji, s. 34-35). Tłumaczenia fragmentów Safony dokonane przez autorkę eseju opublikowane zostały w książce If Not, Winter. Fragments of Sappho, Knopf, New York 2002. [przyp. tłum.] 
Pergamin Marguerite spłonął w 1310 roku. Z naszej perspektywy mógł to być akt przemocy lub pomyłka. Mężczyźni, którzy potępili jej myśl, uznali z pewnością, że we wszystkim się myliła, i w trakcie procesu zwracali się do niej słowami „przepełniona grzechem i herezją" pseudo-mulier, fałszywa kobieto $^{12}$.

Czy Marguerite Porete była fałszywą kobietą?

Społeczeństwo nazbyt chętnie wydaje wyroki w kwestii słuszności dróg, jakimi podążają kobiety, wszystkie te oceny mogą prowadzić do obłędu. Niech za przykład posłuży tu fakt, że książkę, z powodu której Marguerite Porete została spalona na stosie w 1310 roku, przechowali i skopiowali klerycy, od tego czasu tekst funkcjonował jako anonimowe dzieło religijne o chrześcijańskim mistycyzmie, aż do 1946 roku, kiedy włoska badaczka z powrotem skojarzyła Zwierciadło z jego autorką. W tym samym czasie moralny ekstremizm, który z trudem przychodzi nam uznać, przyniósł śmierć Simone Weil, liczącej sobie wówczas trzydzieści cztery lata. Świątobliwość jest erupcją absolutu do powszedniości historii i nie jest to rzecz, która przypadłaby nam do gustu. Potrzebujemy historii, żeby nie wyjść poza przeciętność. Potrzebujemy określać świętość neurozą czy anoreksją, uznawać ją za patologię, skutek seksualnej represji czy fałszerstwo. Takie wyroki uświęcają naszą walkę o przeżycie. Z tego samego powodu starożytni biografowie Safony starali się zdyskredytować powagę jej czynów, zapewniając nas, że jej życie przebiegało w bezgranicznym i chaotycznym seksualnym rozpasaniu, co dało początek lesbijskiej miłości, a zakończyło się śmiertelnym skokiem z klifów z miłości do młodego mężczyzny. Bo jak mówi Simone Weil: „Miłość jest wyrazem istniejącego w nas zła" (SW 111).

Miłość jest też odpowiednim schronieniem dla naszej nieufności wobec pseudo-mulier. W tych trzech kobietach, których teksty czytaliśmy, najbardziej podoba mi się to, że wiedziały, czym jest miłość. To znaczy wiedziały, że miłość jest kamieniem probierczym prawdziwej lub fałszywej duchowości; z tego powodu w grze, jaką toczyły, wykorzystywały figurę zazdrości. Jako niby-kobiety musiały zamieszkiwać tę figurę w sposób roztropny, zajmując pozycję zarazem bliską, jak i daleką względem obiektu swego pożądania. Prawda, o której mówią z tej paradoksalnej pozycji, również jest fałszywa. Jak w uniesieniu stwierdza Marguerite: „Wszystko, co można powiedzieć o Bogu lub napisać, jest tym samym, co można o Bogu pomyśleć, o Bogu,

12 P. Verdeyen Le procès d'inquisition contre Marguerite Porete et Guiard Cressonesart (1309-1310), "Revue d'histoire ecclésiastique" 1986 No 81, s. 47-94. 
który jest czymś więcej niż słowa, zarówno kłamstwem, jak i prawdą" (MP 119).

Nie dać się oszukać przez fałszywe kobiety, o tym powinniśmy pamiętać. Bo jeśli pomylimy taniec zazdrości z bożym uczuciem lub heretyckie zwierciadło z prawdziwą historią, możemy być pewni, że do ostatnich dni będzie nas trawił przerażający głód. Bez względu na to, ile stron przyjdzie nam zjeść.

Przełożył Maciej Topolski

\section{Abstract}

\section{Anne Carson}

UNIVERSITY OF MICHIGAN

Decreation: How Women Like Sappho, Marguerite Porete and Simone Weil Tell God

The essay presents an interpretation of Sappho's poetry as well as the theological works of Marguerite Porete and Simone Weil in the context of the act of decreation - moving aside in relation to the world and to God. Decreation is considered an ecstasy aiming to come closer to God. Ecstasy, however, is an active form of negating consciousness (Being). The figure of a relation with God is jealousy - presented in the movement of dance and allowing to keep a dialectical position (distant and close) to the Creator-lover.

\section{Keywords}

Porete, Sappho, Weil, theology, ecstasy, jealousy 